\title{
The Influence of the Bacterial Environment on the Excystment of Amoebae from Soil
}

\author{
BY LETTICE M. CRUMP \\ Department of Soil Microbiology, Rothamsted Experimental Station, \\ Harpenden, Hertfordshire
}

SUMMARY: Cysts of two amoebae from soil were grown in single-cell cultures to test the effect upon excystment of the presence or absence of bacteria, age and type of bacteria, age of cyst, and the concentration of sodium chloride. Within the limits of the experiments excystment in one species was independent of the presence of bacteria, and unaffected by their age and type or by the age of cyst. The other species was more sensitive and could not excyst without living bacteria of a suitable type, and the cysts become less likely to develop with age. Excystment in both species was adversely affected by increasing the concentration of sodium chloride, distilled water giving the best results.

Living bacteria form the usual food of the small soil amoebae, but numerous references in the literature show that different bacteria have different effects on the amoebae (Frosch, 1897; Mouton, 1902; Oehler, 1916; Tsujitani, 1898; Cutler \& Crump, 1927; Singh, 1941 a). There are also records of other organic particles being eaten, such as small yeasts (Mouton, 1902; Beijerinck, 1896; Oehler, 1916) and dead bacteria (Oehler, 1916; Tsujitani, 1898).

The suitability of a bacterial strain is usually judged either by the rate of reproduction of the amoebae (Cutler \& Crump, 1927) or by the speed with which the bacteria disappear (Frosch, 1897; Singh, 1941 a). Thus single cells of Hartmanella hyalina showed a reproductive rate of 3.7 in the first $24 \mathrm{hr}$. of growth with one species of soil bacteria, and of $2 \cdot 0$ with another, when grown in otherwise identical conditions (Cutler \& Crump, 1927), the time from isolation to excystment being approximately the same in both cases. Singh (1942), using mass cultures, divided his bacteria into groups according to whether they were readily and completely eaten, slowly and completely eaten, slowly and incompletely eaten, or not eaten at all. None of these criteria is wholly satisfactory since the amoebae are observed only up to the time of death or encystment and the ability of the cysts to excyst and carry on the race has not usually been studied. It is, however, well known that the percentage of viable cysts in cultures of Protozoa is very variable (Brand, 1923; Wolff, 1927; Cutler \& Crump, 1927).

Many factors have been stated to induce cyst formation in various genera of Protozoa; among them are the following: lack of food (Beers, 1926; Brand, 1923; Johnson \& Evans, 1940; Oehler, 1916; Singh, 1941 b; Wolff, 1927); crowding (Barker \& Taylor, 1931); desiccation (Belar, 1921; Bodine, 1923; Brand, 1923; Kühn, 1915); gradual evaporation of medium (Garnjobst, 1928); accumulation of waste products of organism (Beers, 1926; Belar, 1921; Mast \& Ibara, 1923; Stolte, 1922); metabolic products of bacteria (Belar, 1921; Kühn, 1915; Mouton, 1902); lack of oxygen (Brand, 1923; Stolte, 1922); alkalinity (Koffman, 1924; Howaisky, 1926); sudden fall in $\mathrm{pH}$ value (Darby, 1929); low tempera- 


\section{Influence of bacterial environment on excystment of amoebae}

tures (Schmahl, 1926); optimum conditions for growth and reproduction (Kater \& Burroughs, 1926); internal causes (Cutler \& Crump, 1935; Ivanic, 1934).

Excystment is attributed to less varied causes on the whole; those most often cited are: addition of fresh liquid (Kühn, 1915); presence of bacteria (Brand, 1923; Frosch, 1897; Singh, 1941 b); presence of oxygen (Brand, 1923); hypertonic solutions (Ilowaisky, 1926); acid pH of medium (Koffman, 1924); desiccation (Rhumbler, 1888; Ilowaisky, 1926; Wolff, 1927); neutral medium (Brand, 1923); organic infusions (Barker \& Taylor, 1933).

It is difficult to discriminate among the various factors which may be present in the same culture at one time, and it is often impossible while varying one factor to keep the others constant; but it is clear that encystment and probably excystment in the Protozoa can be induced by a wide range of conditions, and probably even within one species there is not complete uniformity of behaviour.

\section{MATERIAL AND METHODS}

Two species of limax amoebae from soil (species 4 and species Z) were grown with two species of bacteria: an Aerobacter sp. and a Gram-negative short rod (4036) which is a denitrifying organism isolated from an arable Rothamsted soil. The Aerobacter sp. is recorded by Singh (1942) as being completely and readily eaten by all his amoebae; strain 4036 he found to be inedible (unpublished). After repeated subculturing with strain 4036 on non-nutrient agar plates both amoebae lived successfully on this organism.

The amoebae are of approximately the same size $(15-20 \mu)$, and the active forms are indistinguishable. Amoeba $\mathrm{Z}$ forms a cyst with a single wall; it grows rapidly and in a culture consisting of a circle of bacterial growth of about $1.5 \mathrm{~cm}$. in diameter on a solid medium seeded with a few cysts of the amoebae at the centre, the amoebae usually clear the bacteria completely and have themselves encysted within $24 \mathrm{hr}$. The shortest period for excystment observed is $1.5 \mathrm{hr}$. from the time of isolation. Amoeba 4 forms a double-walled cyst and excystment takes place in two stages: first, the inner wall disappears and a small amoeba moves freely within the outer wall; then, in a successful case, the outer wall gives way and the amoeba emerges. If the outer wall remains impenetrable, as may often happen in unfavourable conditions, the amoeba dwindles away and ultimately dies. The growth and reproduction in this species is not so fast as it is in species $\mathrm{Z}$; a mass culture with the Aerobacter sp. usually takes about 3 days to clear the bacteria and encyst. The most rapid excystment that has been observed in a single cyst is $3 \cdot 0 \mathrm{hr}$.

Mass cultures of both amoebae were grown on non-nutrient agar with bacteria from 1 to 3 days old. $1.5 \%$ agar was used with the addition of $0.5 \% \mathrm{NaCl}$, $0 \cdot 1 \% \mathrm{~K}_{2} \mathrm{HPO}_{4}$ and $0 \cdot 1 \% \mathrm{KH}_{2} \mathrm{PO}_{4}$; the $\mathrm{pH}$ was adjusted to $7 \cdot 0$. The plates were poured at $45^{\circ}$ just before use. Single cysts were grown in counting chambers with the bacteria in sterilized water unless otherwise stated. Since actual excystment is not a guarantee of the animal's vigour, excysted amoebae were kept for $24 \mathrm{hr}$. so that the reproductive rate for that period was known. All cultures were incubated at $25^{\circ}$. 


\section{RESULTS}

The effect on excystment of varying five of the conditions to which the cysts were exposed was as follows.

Amount of sodium chloride in medium. The salt concentration of the solution to which the cysts were exposed affected excystment; more amoebae emerged at the lower concentrations (Table 1), which accords with the findings of Beers (1945) in Tillina magna and Garnjobst (1928) in Euplotes taylori. Relatively few amoebae succeeded in emerging at $\mathrm{NaCl}$ concentrations greater than $0.75 \%$; species 4 was more sensitive than $Z$.

Table 1. Effect of salinity on excystment in 24 hr. in presence of Aerobacter sp.

No. of cysts observed Excystment (\%)

No. of cysts observed Excystment (\%)

\begin{tabular}{|c|c|c|c|c|c|c|}
\hline \multirow[b]{2}{*}{ Amoeba } & \multicolumn{6}{|c|}{$\mathrm{NaCl}(\%)$} \\
\hline & o & $0 \cdot 25$ & 0.5 & 0.75 & $1 \cdot 0$ & 1.5 \\
\hline $\mathbf{Z}$ & $\begin{array}{l}34 \\
97 \cdot 1\end{array}$ & $\begin{array}{l}24 \\
87 \cdot 5\end{array}$ & $\begin{array}{l}\mathbf{4 7} \\
\mathbf{8 2} \cdot 9\end{array}$ & $\begin{array}{l}25 \\
76 \cdot 0\end{array}$ & $\begin{array}{l}488 \\
29 \cdot 2\end{array}$ & $\begin{array}{l}54 \\
14 \cdot 8\end{array}$ \\
\hline 4 & $\begin{array}{l}20 \\
95 \cdot 0\end{array}$ & $\begin{array}{l}85 \\
76.5\end{array}$ & $\begin{array}{l}39 \\
54-5\end{array}$ & $\begin{array}{l}87 \\
44 \cdot 2\end{array}$ & $\begin{array}{l}21 \\
11 \cdot 1\end{array}$ & $\begin{array}{r}21 \\
0\end{array}$ \\
\hline
\end{tabular}

Age of cysts. Within the range of the ages tested (Table 2) the cysts of amoeba $\mathrm{Z}$ showed no significant differences in behaviour, but some of the cysts of amoeba 4 became non-viable with age.

Table 2. Percentage excystment after 24 hr. of single cysts transferred from cultures fed with Aerobacter sp. into water containing Aerobacter sp.

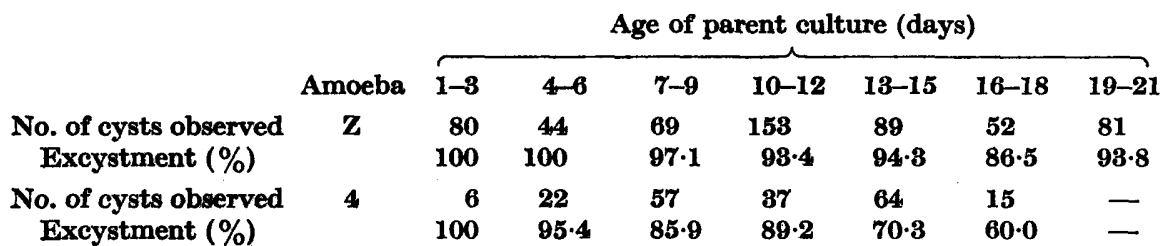

Presence and absence of bacteria. Cysts of amoeba $\mathrm{Z}$ excysted readily in water without bacteria, but those of species 4 excysted very rarely unless living bacteria were present (Table 3). No excystment was observed in species 4 in the absence of living bacteria when cysts were transferred into the supernatant fluid obtained by centrifuging suspensions made from $24 \mathrm{hr}$. old cultures of either of the two bacteria in water.

Table 3. Percentage excystment after $24 \mathrm{hr}$. of single cysts, from cultures grown with Aerobacter sp., placed in water with and without Aerobacter sp.

No. of cysts observed Excystment (\%)

No. of cysts observed Excystment (\%)

$\begin{array}{ccc}\text { Amoeba } & \text { With } & \begin{array}{c}\text { Without } \\ \text { Aerobacter } \text { sp. }\end{array} \\ \text { Aerobacter } \text { sp. } \\ \text { Z } & 114 & 81 \\ & \mathbf{9 2 \cdot 1} & \mathbf{9 3 \cdot 8} \\ 4 & \mathbf{8 6} & \mathbf{8 5} \\ & \mathbf{8 2 \cdot 4} & 0\end{array}$


Age of food supply. In all experiments the numbers of bacteria were very much in excess of the requirements for inducing a maximum reproductive rate, so that even when cysts were transferred to an old culture containing numbers of dead and moribund bacteria there were plenty of living bacteria available. Although in some of the age groups there were not many observations (Table 4) it seems clear that within wide limits the age of the bacteria

Table 4. Percentage excystment after $24 \mathrm{hr}$. in cysts transferred from cultures fed with Aerobacter sp. into water containing Aerobacter sp. cultures of different ages

\begin{tabular}{|c|c|c|c|c|c|c|c|c|}
\hline - r 0 & \multirow[b]{2}{*}{ Amoeba } & \multicolumn{7}{|c|}{ Age of Aerobacter sp. culture (days) } \\
\hline & & $1-3$ & $4-6$ & $7-9$ & $10-12$ & 13-15 & $16-18$ & $18-21$ \\
\hline $\begin{array}{l}\text { No. of cysts observed } \\
\text { Excystment (\%) }\end{array}$ & $\mathbf{Z}$ & $\begin{array}{l}195 \\
96 \cdot 9\end{array}$ & $\begin{array}{l}109 \\
89 \cdot 0\end{array}$ & $\begin{array}{l}14 \\
85 \cdot 7\end{array}$ & $\begin{array}{l}35 \\
77 \cdot 2\end{array}$ & $\begin{array}{l}18 \\
84 \cdot 6\end{array}$ & $\begin{array}{l}26 \\
96 \cdot 1\end{array}$ & $\begin{array}{l}30 \\
80 \cdot 0\end{array}$ \\
\hline $\begin{array}{l}\text { No. of cysts observed } \\
\text { Excystment }(\%)\end{array}$ & 4 & $\begin{array}{l}109 \\
89 \cdot 0\end{array}$ & $\begin{array}{l}53 \\
84 \cdot 9\end{array}$ & $\begin{array}{l}14 \\
92 \cdot 8\end{array}$ & - & - & - & $\begin{array}{l}21 \\
95 \cdot 2\end{array}$ \\
\hline
\end{tabular}

supplied is without effect on the successful excystment of the amoebae. In species 4, however, the age of the bacteria in the medium influences the length of time between isolation and excystment; a few records only have been made, but the result is clear (Table 5 ).

Table 5. Time of excystment of species 4 with Aerobacter sp. of different ages

\begin{tabular}{|c|c|c|c|c|c|}
\hline & \multicolumn{5}{|c|}{ Age of Aerobacter sp. (days) } \\
\hline & $\mathbf{1}$ & 2 & 4 & 9 & More than 9 \\
\hline No. of cysts & 22 & 19 & 16 & 16 & 16 \\
\hline
\end{tabular}

observed

Average time of $3 \mathrm{hr} .20 \mathrm{~min}$. $3 \mathrm{hr} .40 \mathrm{~min}$. $4 \mathrm{hr} .10 \mathrm{~min} .4 \mathrm{hr} .25 \mathrm{~min} .6 \mathrm{hr} .40 \mathrm{~min}$. excystment

Strain of bacterium to which cysts were exposed. Cysts formed in cultures with the Aerobacter sp. and $\mathbf{4 0 3 6}$ were grown with both types of bacteria. Species $\mathbf{Z}$ is very little affected by the change in bacteria, but in species 4 there is a difference in response (Table 6).

Table 6. Percentage of excystment after $24 \mathrm{hr}$. for amoebae $Z$ and 4 transferred to water

\begin{tabular}{|c|c|c|c|}
\hline \multirow{3}{*}{$\begin{array}{l}\text { Cysts formed with Aerobacter sp.: } \\
\text { No. of cysts observed } \\
\text { Excystment (\%) }\end{array}$} & \multirow{3}{*}{$\begin{array}{c}\text { Amoeba } \\
4\end{array}$} & \multicolumn{2}{|c|}{ Bacteria in medium } \\
\hline & & Aerobacter sp. & 4036 \\
\hline & & $\begin{array}{l}263 \\
91.2\end{array}$ & $\begin{array}{l}219 \\
32 \cdot 3\end{array}$ \\
\hline $\begin{array}{l}\text { No. of cysts observed } \\
\text { Excystment (\%) }\end{array}$ & $\mathbf{z}$ & $\begin{array}{l}223 \\
94.5\end{array}$ & $\begin{array}{l}60 \\
96 \cdot 6\end{array}$ \\
\hline $\begin{array}{l}\text { Cysts formed with } 4036: \\
\text { No. of cysts observed } \\
\text { Excystment ( } \%)\end{array}$ & 4 & $\begin{array}{l}201 \\
98 \cdot 6\end{array}$ & $\begin{array}{l}179 \\
45 \cdot 5\end{array}$ \\
\hline $\begin{array}{l}\text { No. of eysts observed } \\
\text { Excystment (\%) }\end{array}$ & $\mathbf{Z}$ & $\begin{array}{l}\mathbf{8 0} \\
95 \cdot 0\end{array}$ & $\begin{array}{l}80 \\
95 \cdot 0\end{array}$ \\
\hline
\end{tabular}




\section{CONCLUSIONS}

Since species 4 cannot excyst without bacteria it seems that these two strains of bacteria produce some material inducing excystment in this amoeba (Thimann \& Barker, 1984), but that the product of the Aerobacter sp. is the more efficacious. The unsuccessful attempts already recorded to induce excystment by placing the cysts in culture fluid in which Aerobacter sp. or 4036 had grown, but from which they had been removed by centrifuging, suggest that the substances concerned may be so transient that they disappear as fast as they are formed, and only when there are living bacteria in the medium is enough of the stimulating material present to act successfully on the cysts.

It can be argued either that in the presence of strain 4036 the amoebae produce a cyst wall which is relatively weak, or that the amoebae which ultimately survive on 4036 are a tougher race and give rise to a higher percentage of viable cysts.

Cysts of species 4 with the Aerobacter sp. showed a consistently high rate of excystment whether they had been formed in the presence of Aerobacter or of 4036 (Table 6), but when such cysts were grown with 4036 there was a marked decrease in the numbers which excysted. Cysts formed in cultures fed with 4036 showed a significantly higher rate of excystment than those from an Aerobacter parentage; where the cysts were grown with Aerobacter the difference was not so marked, 91.2 and $98.6 \%$, though this difference is significant at the $5 \%$ level, but in isolations with 4036 the difference was as between $32 \cdot 3$ and $45.5 \%$, which is highly significant.

I wish to thank Dr H. G. Thornton, F.R.S., and Dr B. N. Singh for suggestions. I am indebted to Mr J. H. A. Dunwoody for determining the significance of the figures given in Table 6 .

\section{REFERENCES}

Barker, H. A. \& TAYLor, C. V. (1931). A study of the conditions of encystment of Colpoda cucullus. Physiol. Zoöl. 4, 620.

Barker, H. A. \& TAyTor, C. V. (1933). Studies on the excystment of Colpoda cucullus. Physiol. Zoöl. 6, 127.

BeErs, C. D. (1926). The life-cycle in the ciliate Didinium nasutum with reference to encystment. J. Morph. 42, 1.

BEERs, C. D. (1945). Some factors affecting excystment in the ciliate Tillina magna. Physiol. Zoöl. 18, 80.

Beijerinck, M. W. (1896). Kulturversuche mit Amoeben auf festen substrate. Zbl. Bakt. (1 Abt., Orig.), 19, 257.

BeLAR, K. (1921). Untersuchungen ueber Thecamoeben der Chlamydophrys-Gruppe. Arch. Protistenk. 43, 287.

Bodine, J. H. (1923). Excystation of Colpoda cucullus. J. exp. Zool. 37, 115.

Brand, Tr. v. (1923). Encystierung bei Vorticella microstoma und hypotrichen Infusorien. Arch. Protistenk. 47, 59.

Cutler, D. W. \& Crump, L. M. (1927). The qualitative and quantitative effects of food on the growth of a soil amoeba (Hartmanella hyalina). Brit. J. exp. Biol. 5, 155.

Cutlare, D. W. \& Crump, L. M. (1935). The effect of bacterial products on amoebic growth. Brit. J. exp. Biol. 12, 52. 


\section{Influence of bacterial environment on excystment of amoebae}

Darby, H. H. (1929). The effect of the hydrogen-ion concentration on the sequence of protozoan forms. Arch. Protistenk. 65, 1.

Froscr, P. (1897). Zur Frage der Reinzuchtung der Amoeben. Zbl. Bakt. (1 Abt.), 21, 926.

GarnJoBst, L. (1928). Induced encystment and excystment in Euplotes taylori, sp.nov. Physiol. Zoöl. 1, 561.

InowaIsky, S. A. (1926). Material zum Studium der Cysten der Hypotrichen. Arch. Protistenk. 54, 92.

IVanic, M. (1934). Ueber die Ruhestadienbildung und die damit am Kernapparate verbundenen Veranderungen bei Lionotus cygnus O.F.M. (Amphileptus anser Ehrbg.). Zool. Anz. 108, 17.

Jomnson, W. H. \& Evans, F. R. (1940). Environmental factors affecting encystment in Woodruffia metabolica. Physiol. Zoöl. 13, 1.

KATER, J. McA. \& Burroughs, R. D. (1926). The cause and nature of encystment in Polytomella citri. Biol. Bull. Woods Hole, 50, 38.

Korman, M. (1924). Ueber die Bedeutung der Wasserstoffionenkonzentration für die Encystierung bei einigen Ciliatenarten. Arch. mikr. Anat. 103, 168.

KüHN, A. (1915). Ueber Bau, Teilung und Encystierung von Bodo edax Klebs. Arch. Protistenk. 36, 212.

Mast, S. O. \& Ibara, Y. (1923). The effect of temperature, food and the age of the culture on the encystment of Didinium nasutum. Biol. Bull. Woods Hole, 45, 105.

Mouton, H. (1902). Recherches sur la digestion chez les amibes et sur leur diastases intracellulaire. Ann. Inst. Pasteur, 16, 457.

Oterher, R. (1916). Amobenzucht auf reinem Boden. Arch. Protistenk. 37, 175.

Rhumbler, L. (1888). Die verschiedenen Cystenbildungen und die Entwicklungsgeschichte der holotrichen Infusoriengattung Colpoda. Z. wiss. Zool. 46, 449.

Schmahl, O. (1926). Die Neubildung des Peristoms bei der Teilung von Bursaria truncatella. Arch. Protistenk. 54, 359.

Singr, B. N. (1941a). Selectivity in bacterial food by soil amoebae in pure mixed culture and in sterilized soil. Ann. appl. Biol. 27, 52.

Singh, B. N. (1941b). The influence of different bacterial food supplies on the rate of reproduction in Colpoda steinii, and the factors influencing encystation. Ann. appl. Biol. 27, 65 .

Singh, B. N. (1942). Selection and bacterial food by soil flagellates and amoebae. Ann. appl. Biol. 29, 18.

Stolte, A. H. (1922). Verlauf, Ursachen und Bedeutung der Encystierung bei Blepharisma. Verh. dtsch. Zool. Ges. 27, 79.

Thmmann, K. V. \& Barker, H. A. (1934). Studies on the excystment of Colpoda cucullus. II. The action of the excystment inducing substance. J. exp. Zool. 69, 37.

Tsujitan, J. (1898). Ueber die Reinkulturen der Amoeben. Zbl. Bakt. (1 Abt.), 24, 666 .

WoLfF, E. (1927). Un facteur de l'enkystment des Amibes d'eau douce. Prolongation experimentale de la periode vegetative. C.R. Soc. Biol., Paris, 96, 636. 